\title{
Quantification of Sand Dune Movements in the South Western Part of Egypt, Using Remotely Sensed Data and GIS
}

\author{
Islam Abou El-Magd*, Osman Hassan, Sayed Arafat \\ National Authority for Remote Sensing and Space Science (NARSS), Cairo, Egypt \\ Email: ${ }^{*}$ imagd@narss.sci.eg
}

Received July 15, 2013; revised August 8, 2013; accepted September 8, 2013

Copyright (C) 2013 Islam Abou El-Magd et al. This is an open access article distributed under the Creative Commons Attribution License, which permits unrestricted use, distribution, and reproduction in any medium, provided the original work is properly cited.

\begin{abstract}
Sand dune movement is a hazardous phenomenon in Egypt and creates major threat on the existing land use and land cover as well as developmental plans. This paper studied the sand dune morphology and quantified the rate of sand dune movements and direction in a newly developed project in the southwest of Egypt. Two dates of satellite imageries were used to trace the Barchan dunes at various sites with different morphological properties to estimate the annual movement rate based on point to point geo-correlations. 149 dunes of the common sand dunes in the area of study including barchans and transverse dunes were studied to accurately determine their rate of movements, which ranged from 1.3 to $19.3 \mathrm{my}^{-1}$. The direction of sand dune movements was mainly to the south and slightly southeast with range from 265 to 295 degrees. The quantification of sand dune movement and direction has, indeed, enabled to determine the major threat on the exiting land use and land cover as well as the newly developmental projects.
\end{abstract}

Keywords: Sand Dune; Natural Hazards; Remote Sensing; GIS; Egypt

\section{Introduction}

Egypt population is $\sim 90$ million, which, however, settles on just $6.6 \%$ of the Egyptian territory along the flood plain of the Nile Delta and the River Nile [1]. The over increase of population has inspired both government and individuals for lateral spread towards the desert land. One of the main targeted areas for lateral expansion is the western desert but at specific localities such as the western corner of the western desert. In this area, the government initiated huge developmental projects including agriculture, urban and medical tourism. Various prominent projects have been developed in this area including land reclamation for agricultural purposes such as Toshka Project. However, the main issue was the availability of water and suitability of land [2,3]; critical missed issue was the risk of the natural hazards particularly of sand dune movements. Therefore, the success of such promising projects basically relies on understanding the dynamic of geomorphic landscapes that host these projects [4-7].

The aeolian deposits cover about $16 \%$ of the total Egypt territory, which constrain the expansion of development and always create threat on the existing land use

${ }^{*}$ Corresponding author. and land cover [8-10]. This includes various types of sand seas, sand fields, sand plains and sand sheets [11,12]. The area of study is part of this dynamic aeolian system that is controlled by various earth surface processes, which produce vast areas of sand dunes representing a sever hazard $[13,14]$. Under arid conditions, where the evaporation rates exceed the precipitation rates; and the vegetation is scarce, sand dunes move at various rates and directions. Determination of the rates of sand dune movements and their spatial extensions is for the protection of both natural recourses and man-made projects.

Many previous researches on the detection and measurement of sand dune movements in Egypt have followed the conventional methodologies of ground based techniques which include sand traps, steel and iron rods $[15,16]$, and fluorescent dye [17]. At El-kharga depression, the same techniques have estimated the sand dune movements at $10-18 \mathrm{~m} /$ year [18]. Although these techniques show a high level of accuracy, they provide measurements on specific localized sand dune at monthly or seasonal interval. Since they rely on targeted field measurements, these methods inherently lack the capability to monitor wide coverage. In addition, they are not cost-ef- 
fective: consume time, effort, and money.

Remote sensing techniques could be used effectively to monitor sand dune movements through comparing the multi-temporal satellite images [19-22]. Unlike field measurements, remotely sensed data show regular and wide coverage for analysis and measurements [23,24]. Furthermore, although satellite imagery provides multi-temporal coverage of large areas at low coast, the classical definition of sand dune boundaries is highly affected by satellite geometry and illumination conditions $[25,26]$. It [27] was visually interpreted remotely sensed data were to determine Oman's Wahiba Sand dunes of different sizes, and were able to relate the dune types to the dominant wind regime over both the short term periods. In-depth analysis of remotely sensed data could enable to classify sand dunes. Researchers [8] used this approach to classify sand dunes into three main categories:

1) Migrating dunes, in which the whole dune body advances with little or no change in shape and dimensions. The typical case of this category is the barchans, whose morphology is relatively simple $[28,29]$ and transverse and crescent [30];

2) Elongating dunes, in which the length of the dunes increases over time by means of processes that differ strongly from those that affect migrating dunes. This category is mostly represented by linear dunes; and

3) Accumulating dunes, in which the dunes exhibit little or no net advance or elongation. Migrating dunes are the most active group of dunes, and their migration can cause major threat on infrastructures and both land use and land covers such as roads, farmland [31-33].

The area of study has a high level of Barchan dune movement; which varies from 20 to $100 \mathrm{~m} /$ year, and exhibits strong correlation with effective winds, dune size, ground length of the windward side and mean slope angle of the windward side [14-38]. Analysis of the wind data at the Kharga station indicated that about $95 \%$ of the effective wind is coming from the north direction at speed of $20 \mathrm{~km} / \mathrm{hr}$ which actively moves the smaller dunes at faster rate than the larger ones. This is due to the sand mass transported decreases, as the dune gets smaller. Indeed, the land use and cover are playing a major role in such movements where the vegetation cover minimizes the movements and stabilizes the sand dunes [34].

In this research, remotely sensed data as a source of information and GIS techniques were used to trace the dune morphology and determine the sand dune movements in integrated manner to provide a baseline for operational system for sand dune hazard in the area of study.

\section{Study Area}

Toshka depression area is located in the south Western Desert of Egypt, at about $250 \mathrm{~km}$ southwest of Aswan city, between latitudes $22^{\circ} 30^{\prime} \mathrm{N}-23^{\circ} 45^{\prime} \mathrm{N}$ and longitudes $30^{\circ} 0^{\prime} \mathrm{E}-31^{\circ} 30^{\prime} \mathrm{E}$ (Figure 1). The Toshka depression is bounded by Sinn EL-Kaddab plateau from the north, which is capped by Paleocene and Eocene limestone and chalk. It is hosting two aeolian features of great importance as a source of dune in the area.

The area is nearly flat in the eastern side with altitude of 90 meter above sea level (ASL), which inspired the Egyptian government for reclamation and development of this area. It was planned to utilize the excess water of Lake Nasser (above $178 \mathrm{~m}$ ASL) via spillway through a main irrigation canal (Sheikh Zayed Canal) for agricultural development [35]. It is, however, dominated by the presence of numerous moving dunes organized by several groups that has major threat on such developmental plans. This includes an extensive belt of Barchan-type sand dunes which crosses the western part of the Toshka depression in a North-South direction. This is together with the huge longitudinal dune belt, which enters Toshka area from the North. The second feature is the small sand dues area which lies on the plateau surface and extend south to Toshka area. The climatic conditions of the region play an important role in shaping the landscape and the ecology of Toshka area. It is a typical of hyper-arid with rare rainfall and high temperature most of the year with an average air temperature of $33^{\circ} \mathrm{C}$ in summer and $16^{\circ} \mathrm{C}$ in winter. Wind speed and direction is the driving force of sand dune movements is this area, which is windy most of the year with average wind speed $6 \mathrm{~m} \cdot \mathrm{sec}^{-1}$.

\section{Materials and Methods}

Two dates of satellite images were used in this study, which are Landsat Thematic Mapper dated 2000 and Spot Image dated 2006. Complementary data of geological maps and topographic maps at scale 1:100,000 were used to generate other thematic layers. The satellite images were geometrically corrected to the Universal Transverse Mercator (UTM) projection system (zone 36). They also radiometrically corrected to remove the effect of aerosols from the atmosphere for further analysis. Enhancement techniques were applied including band-combination and band-rationing for visual interpretation and identification of the sand dune.

The enhancement techniques of histogram equalization and edge detection enabled for clear distinguish of sand dune ridges and outlines based on differences in the brightness of various dune features; for example lee slopes were bright and windward slopes were dark. Conversely, the sparsely undulated inter-dune residual hilly land usually appeared as gray zones in the satellite images. This is because different parts of the dunes create different angles of light reflection as a result of the geometry of the sun-dune-sensor system. The light reflected by slopes of barchans and dune ridges, with little light reflected 


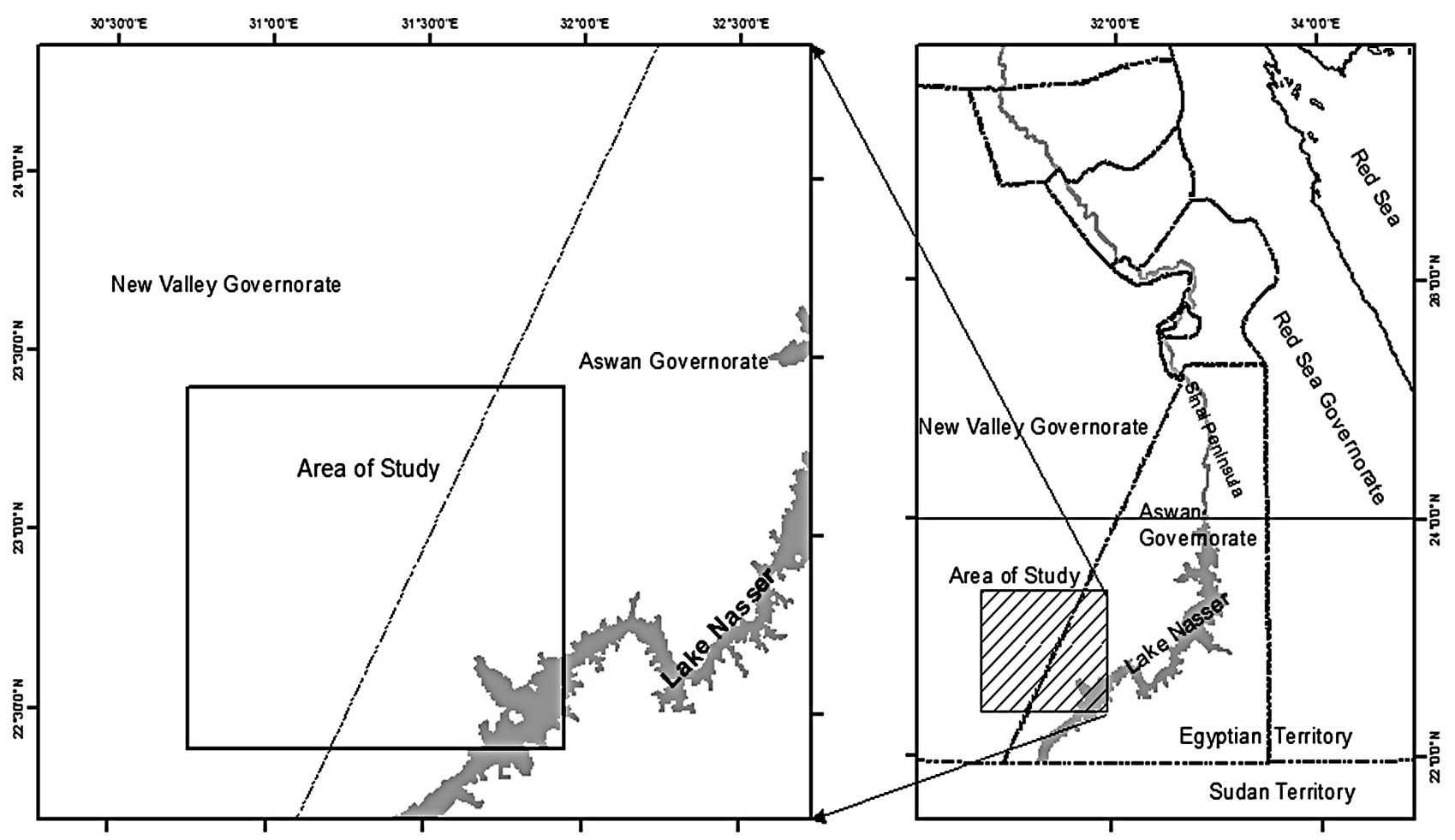

Figure 1. Area of study.

back by inter-dune ridges, which captured a dark image. Therefore tracing these sand dunes particularly selected barchans dunes for geographical correlation and computation of the movement rate was carried out.

Figure 2 shows the systematic technical approach of studying the dune morphology and determining the rate of sand dune movements. This is based on the fact that Barchan dune moves with self-preserving its shape, which maintains equilibrium of erosion and sand deposition rates. Sand is transported from the stoss to the dune lee side causing the dune to migrate (Figure 3 ). The main mechanism is saltation of sand transport using the wind which is a typical surface rolling. The crest becomes unstable and sand avalanches occur down the slip face. The key methodological steps are:

1) Selection of identical two point coverage to represent the individual dune in each image, either on specific points on the lee of the sand dune or the centre point, this is mainly based on crest-to-crest (concave-to-concave) correlation. Figure 3 shows a field picture of Barchan dune with the points actually in use for the correlation.

2) Extracting the geographic coordinates of each studied dunes including X \& Y tie points.

3) Compute the total movement distance using this equation:

DIStotal $=\sqrt{\left(\mathrm{X}_{\text {dif }}\right)^{2}+\left(\mathrm{Y}_{\text {dif }}\right)^{2}}$

4) Compute the movement direction angle using this equation:

$$
\text { MOVangle }=T A N^{-1}(\text { Ydif } / \text { Xdif })
$$

5) Then compute the average rate of sand dune movement per year averaging the whole points using this equation.

DIStotal $/ n$, where $n$ is the number of calculated points

6) Compute the average sand dune movement in the study area by averaging the dune movements in the 5 pilot areas (Figure 3).

The level of accuracy is subjected to the tracing of the sand dunes which is merely controlled by the experience of identification of the sand dune. To minimize the error arises from the determination of detecting the dune outlines, geomophological expert who traced the outlines of these dunes and supported with the field verification and GPS points. Secondly, there is another error arises from the difference in the spatial resolution between the Landsat image (30 meter) and SPOT image (20 meter). Resolution merge of the TM multi-spectral with the panchromatic to improve the spatial resolution of the TM image to 15 meter. This has minimized the difference between both images, which consequently minimized the error at an acceptable level for such application.

Five selected pilot areas were chosen to study the dune morphology and determine the sand dune movements, which are covering most of the environment of the region and covering most of the area subjected for development. Figure 4 below shows the location of these pilot areas, which are numbered from 1 to 5 that will be intensely studied for sand dune migration. 


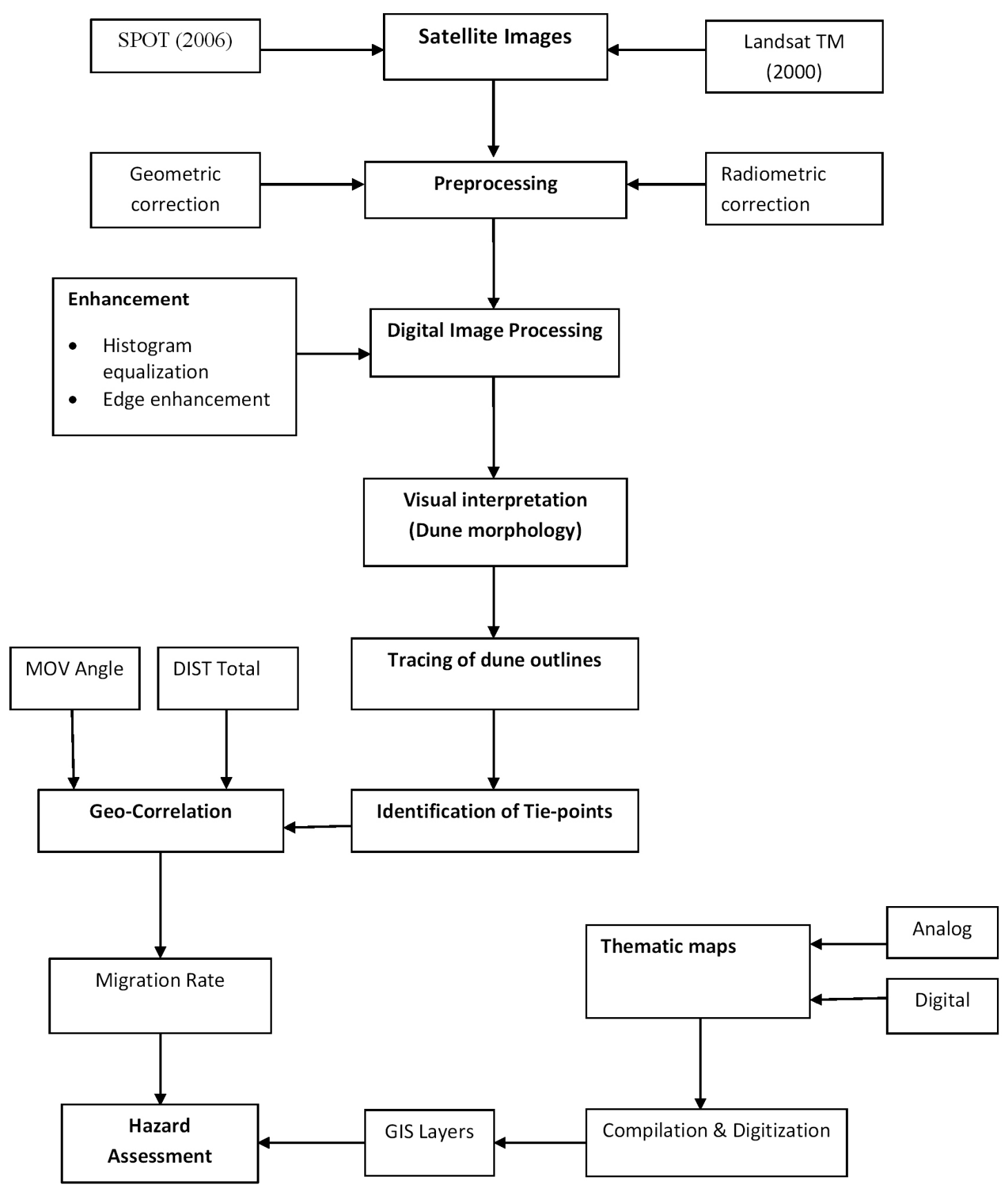

Figure 2. Flow chart of methodological approach.

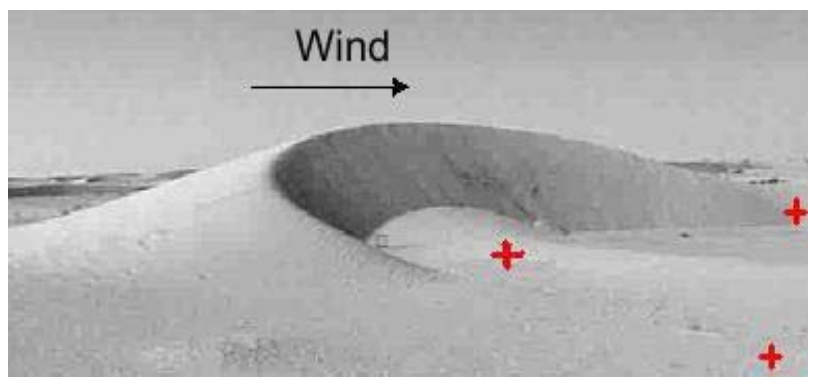

Figure 3. Typical Barchan dune in the field with the proposed reference tie-points (red cross) for geo-correlation.

\section{Results}

\subsection{Dune Morphology and Pattern of Distribution}

South western desert of Egypt is occupied by a very complicated wind system, which is characterized by multidirections and intensities. These wind systems are the main driving force of assembling the dynamicity of the geomorphic features in the area of study as well as assembling various sand dune systems that vary from longitudinal to Barchan as well as transverse dunes. The 


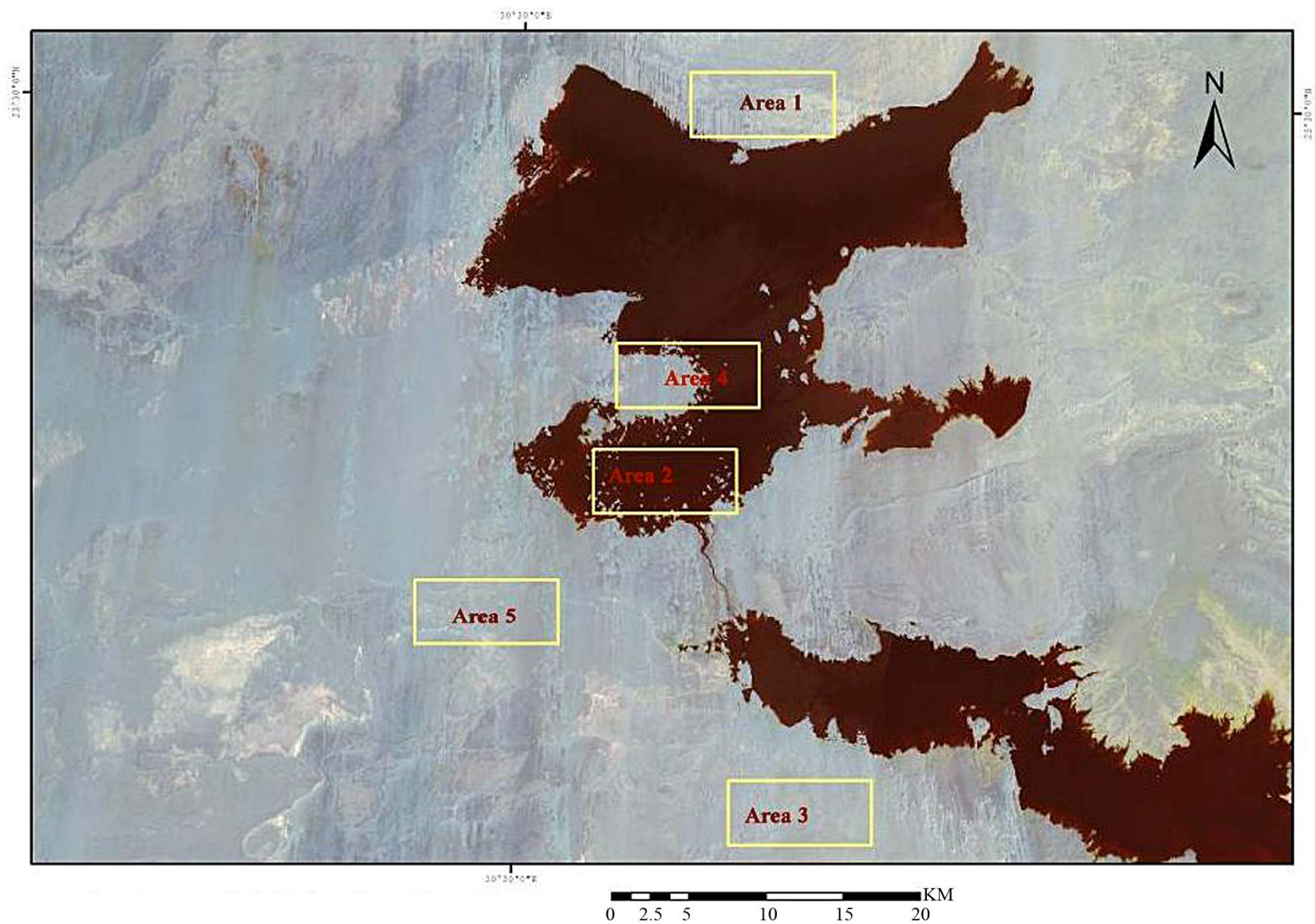

Figure 4. The five selected pilot areas (surrounding the spillway of Toshka lakes).

dominant climatic condition in this region is arid to hyper-arid with low precipitation and high evaporation rates along with scarce vegetation cover. This creates a typical environment for sand dune movements at different rates and directions. The dune morphology of the study area is dominated by Barchan and transverse dunes; the interpretation of the satellite images has shown no major changes in dune morphology. However, the changes in the wind regime (magnitude and direction) have result in minor changes in the dune outlines which used to measure the migrated distance between the two dates.

Dune belts that occupy the wind corridors were clearly determined in 2000 and 2006 satellite images. Four recognizable geometrical forms of sand dune were defined in the study area including:

1) Ripple dunes forming successive waves over sand sheets or rocky surfaces;

2) Small individual barchans;

3) Sheet dunes; and

4) Sand sheets and shadows.

Digital image processing of enhancement of the satellite images enabled to determine and trace the outlines of these belts, which show major changes in the dune outlines and growth in 6 years (i.e. movements). Figure 5 shows the overlaid traced outlines of the sand dunes in both dates of the satellite images, which clearly show the advancement of the sand dune. The advanced dunes are often in the dominated wind direction (to the south in this figure).

The pilot areas 1,2 and 5 have occupied and maintained the same shape of Barchan dunes with general migration direction to the south in the same direction of the wind that influences the migration in this direction. However, dunes at pilot areas 3 and 4 are more complex in their shapes, including transverse dunes, and movements; which is a reflection of the multiple wind directions influencing these two pilot areas.

The in-depth visual interpretation of the satellite image [1] has enabled to understand the source of the sand dunes in the area of study. It is almost generated from the north where the large dune field of Abu Muharik exists. Other dune source is from the narrow dune belts that occur parallel to the western side of the Nile Valley between the two neighbourhood governorates of Beni-Suef and Aswan. The visual interpretation of the study area has also confirmed the existence of the interdunal depressions, which are generally undulating the low topographic areas between the sand dune belts. 


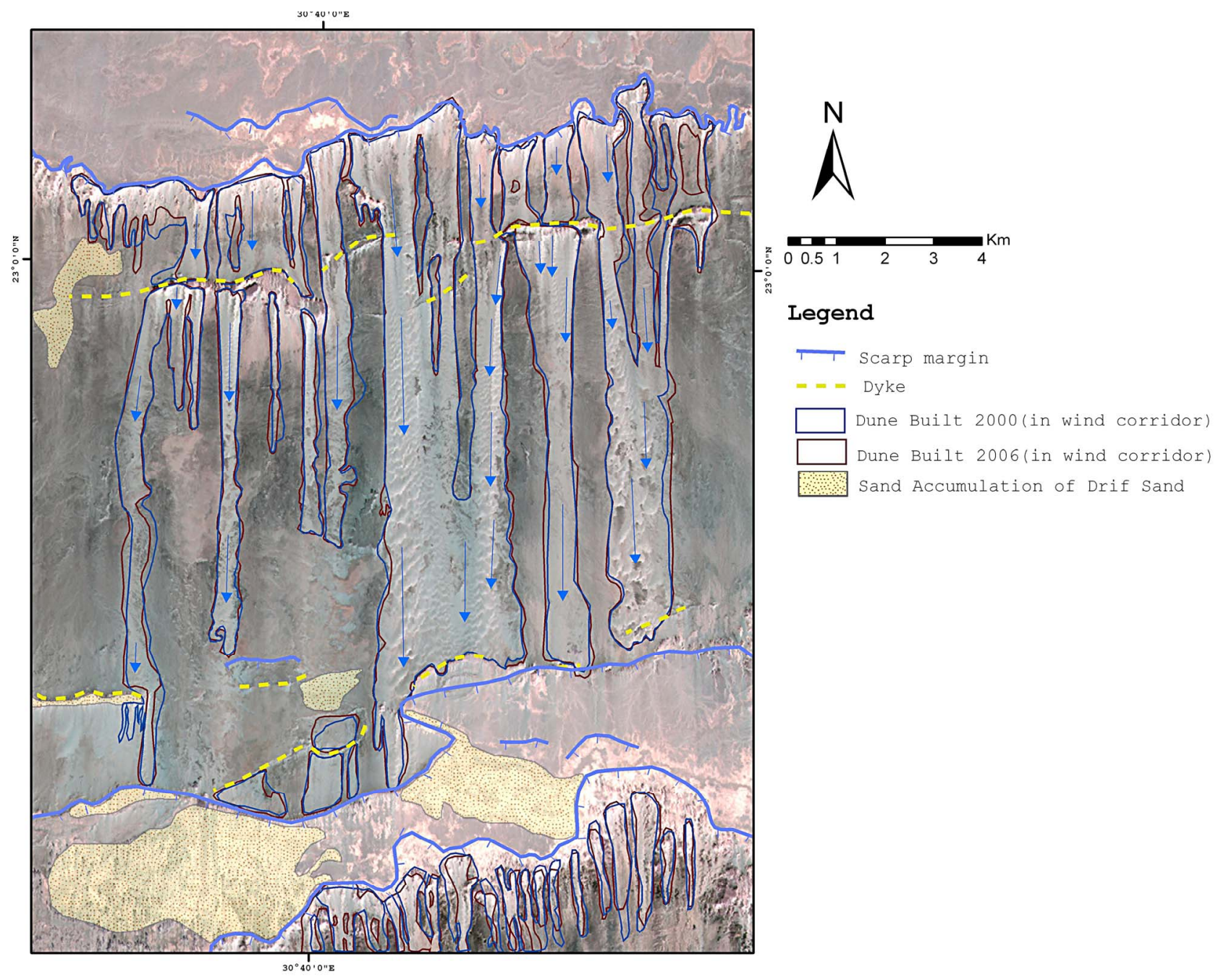

Figure 5. Changes in the dune outlines and ridge positions from 2000 to 2006.

Determining the magnitude of sand dune movements and direction were based on tracing the multi-temporal border of sand dunes for correlation and spatial determination. The spatial extension of the sand dunes provides the main direction of movements and magnitude of movements.

\subsection{Dune Migration Rates}

To determine the actual sand dune movements, geographic correlation between the individual dunes was measured using the correlated points on the outlines of the dunes either on the lee or crest of the dune.

The pilot area 1 is located northern the Toshka lake which occupied by typical barchans dunes. 12 points were chosen on typical four Barchan dunes to measure the locational difference as function of the migration of the dunes. The two dates of the satellite images maintained the same shape and morphology of the Barchan dunes with movements southwards (Figure 6). The one-to-one point geo-correlation between the two images estimated the minimum sand dune movements of $1.3 \mathrm{my}^{-1}$ and the maximum of $3.7 \mathrm{my}^{-1}$ with a yearly average of movements during the 6 years of $2.3 \mathrm{my}^{-1}$. The general direction of movement is slightly to the south east, with average movement angle of 290 degrees.

Pilot areas 2 and 4 are located within the Toshka lakes, which are occupied by barchans, elongated and irregular shaped dunes. 10 points were chosen on 7 different dunes outlines representing the majority of the sand dunes in the pilot area 2 to determine the displacement of these outlines as function of the migration of the dunes in this particular area. The two dates of the satellite images showed that the dune morphology is maintained with continual movements to the south (Figure 7). The oneto-one point geo-correlation between the two images estimated the minimum movements of $1.45 \mathrm{my}^{-1}$ and the maximum of $11.95 \mathrm{my}^{-1}$ with a yearly average movements of the 6 years of $7.1 \mathrm{my}^{-1}$. The general direction of movement is slightly to south east, with average move- 


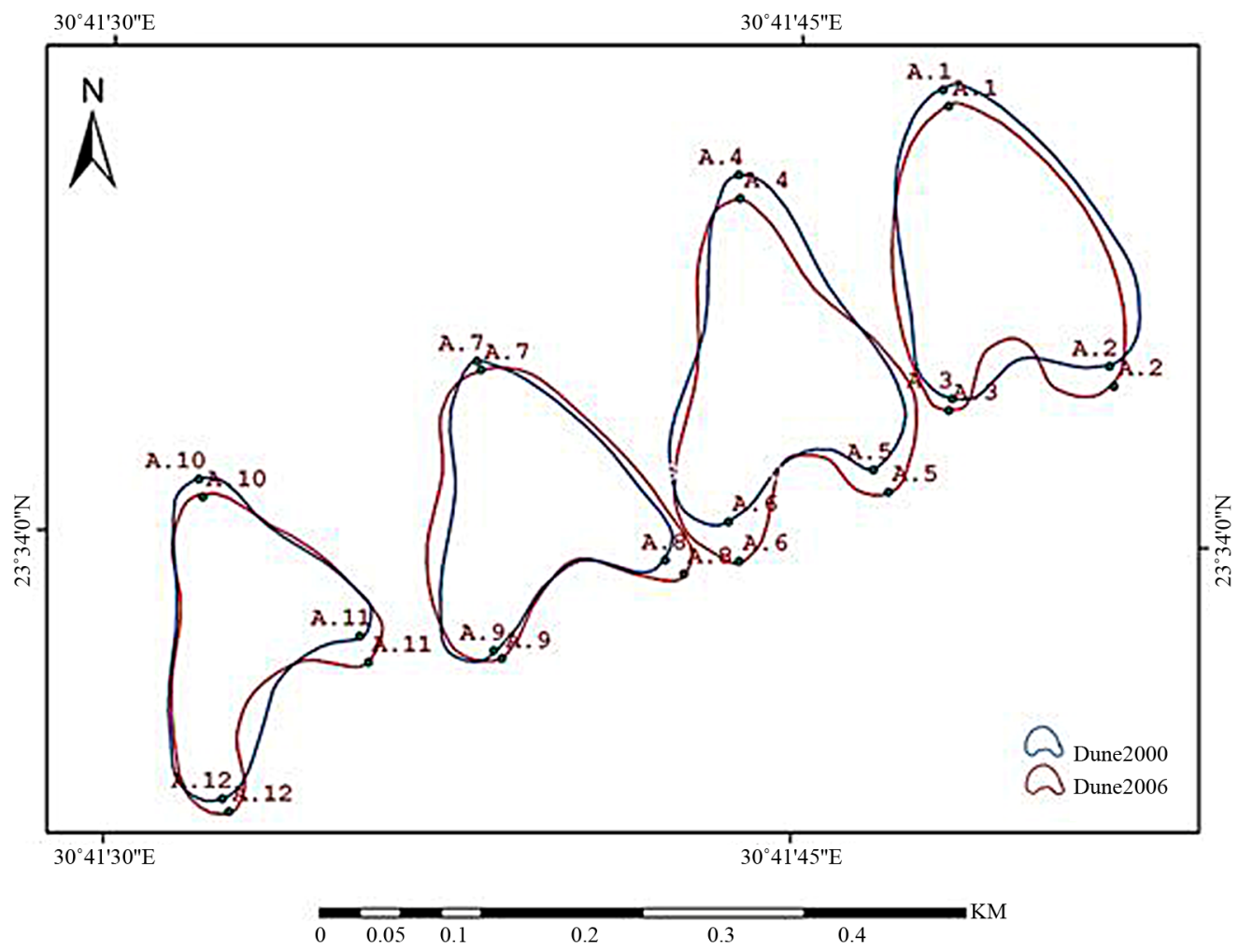

Figure 6. Barchan dune movements at pilot area 1.

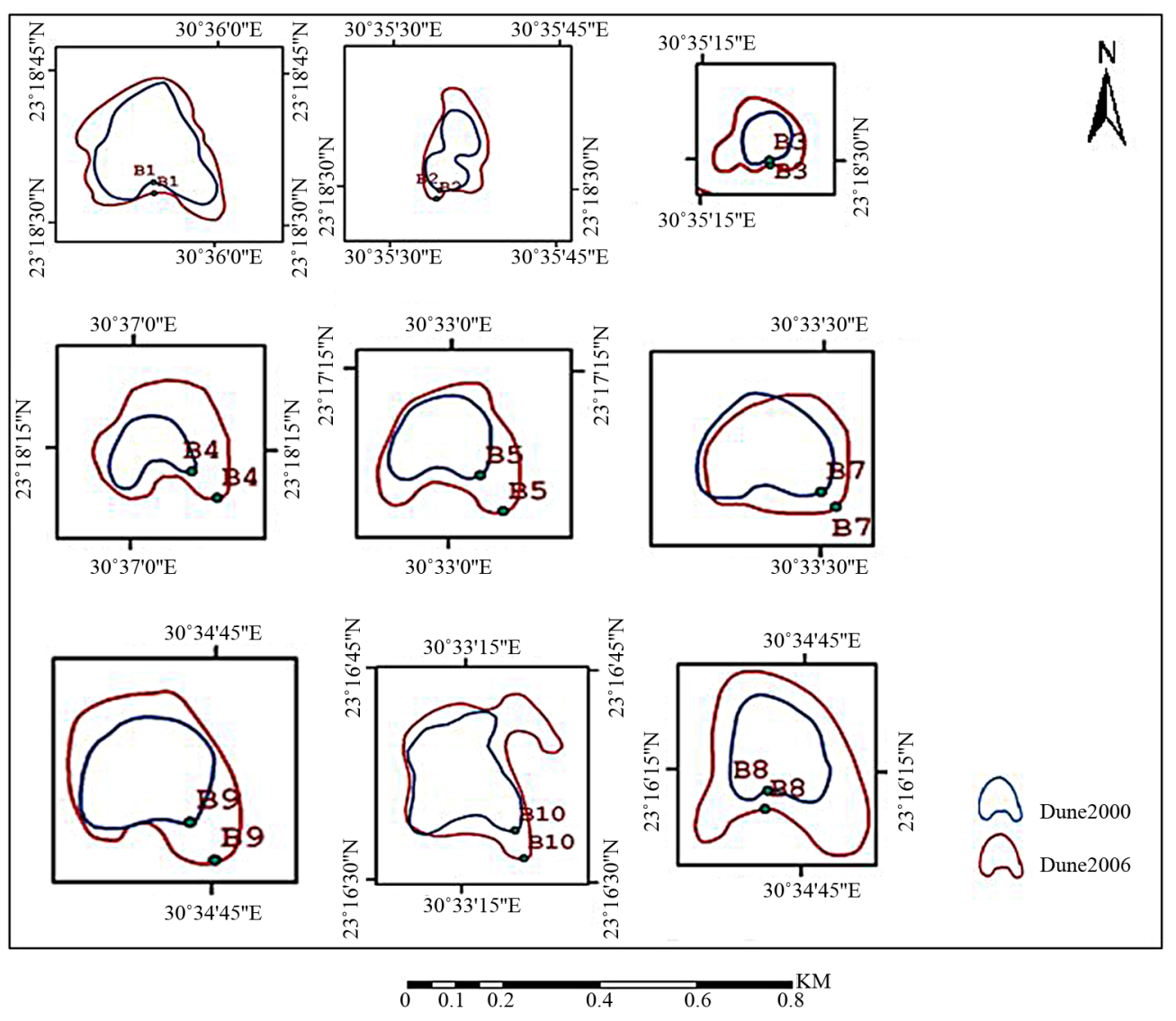

Figure 7. Dune movement at pilot area 2. 
ment angle of 275 degrees.

However, in pilot area 4: 13 points were distributed on 6 dunes of the pilot area 4 (Figure 8). The displacement between these points estimated the minimum movements of $2.1 \mathrm{my}^{-1}$ and the maximum of $16.9 \mathrm{my}^{-1}$ with a yearly average movements in the 6 years of $6.85 \mathrm{my}^{-1}$. The general direction of movement is slightly to the south east, with average movement angle of 295 degrees.

These 2 pilot areas (2\&4) have influence on the Toshka lakes by moving the sand to the lakes and create threat on the siltation of the lakes.

The last two pilot areas 3 and 5 are located to the south of the spillway of Toshka lakes, which occupied by barchans and few irregular small dunes. 15 points were chosen on 5 different sand dunes outlines representing the majority of the dunes in the pilot area 3 to determine displacement of these outlines as function of the migration of the dunes. The two dates of the satellite images shows maintained shapes and morphology of the Barchan dunes with migration to the south (Figure 9). The point-topoint geo-correlation between the two satellite images estimated the minimum movements of $1.8 \mathrm{my}^{-1}$ and maximum of $6.7 \mathrm{my}^{-1}$ with an average yearly movements of the 6 years of $3.9 \mathrm{my}^{-1}$. The general direction of movement is slightly to the south east, with average movement angle of 270 degrees.
However, 39 points were distributed on 15 dunes of the pilot area 3 (Figure 10). The measured displacement between these points giving minimum movements of 2.9 $\mathrm{my}^{-1}$ and maximum of $19.3 \mathrm{my}^{-1}$ with an average yearly movements of the 6 years of $6.8 \mathrm{my}^{-1}$. The general direction of movement is to the south, with average movement angle of 265 degrees.

\section{Discussion}

Sand dunes are very common phenomena in Egypt, which occupy nearly $17 \%$ of the Egyptian territory. These sand dunes are actively migrating creating a major threat on the human activities and existing land use and land cover. Detecting the magnitude of sand dune movements as well as the direction could significantly help in reducing their adverse threat particularly on the newly developed projects such the area of study.

The area of study, southern part of the western desert, is subjected to hyper arid environment with multi-directional wind system that accelerates the sand dune movements and low precipitation to stabilize such dune movements. Figure 11 is a simulation of the dominant wind direction in the region of the study area, which shows variable directions with major dominant direction of north-south that always crosses the spillway of Lake Nasser.

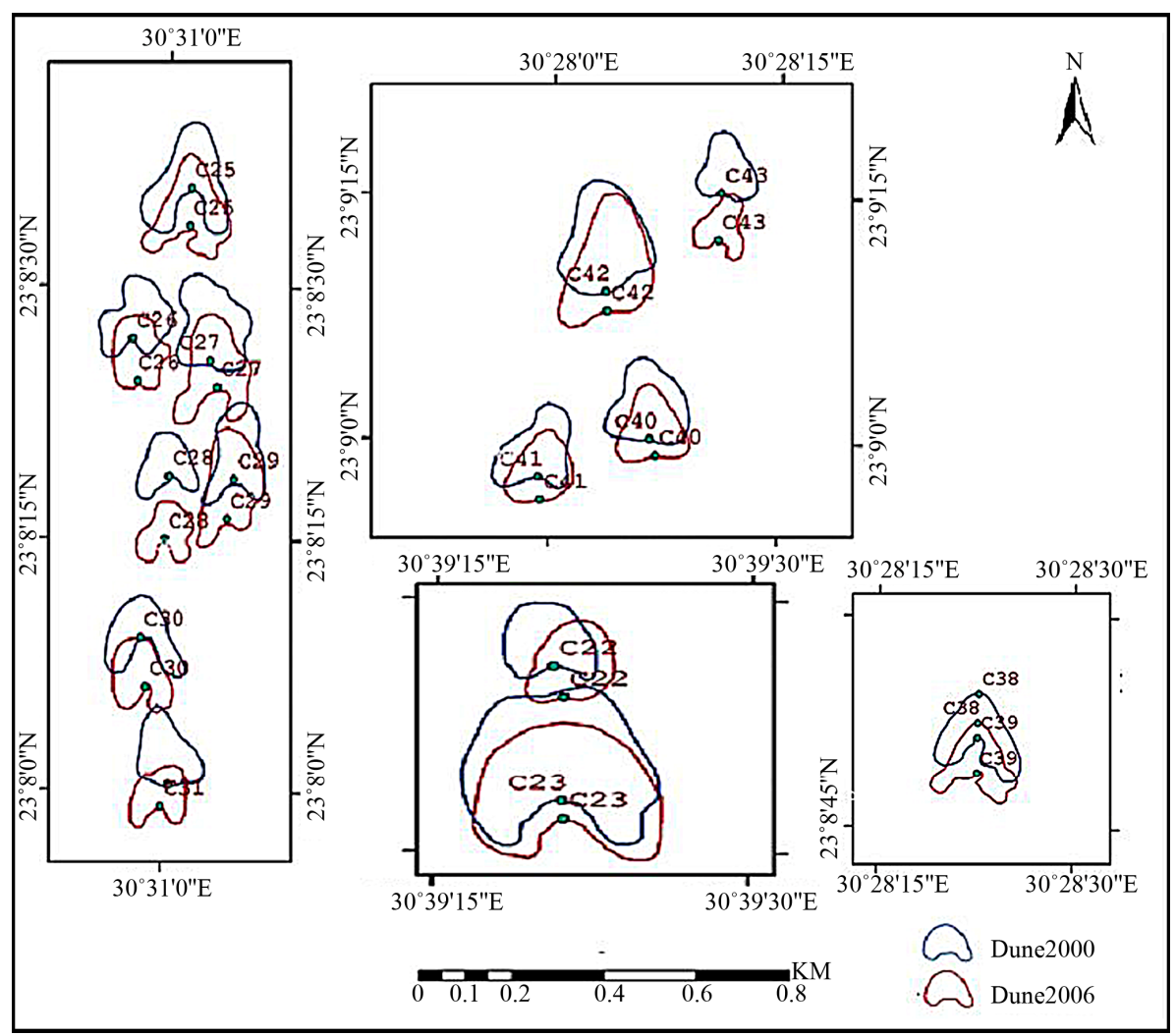

Figure 8. Dune movements at pilot area 4. 


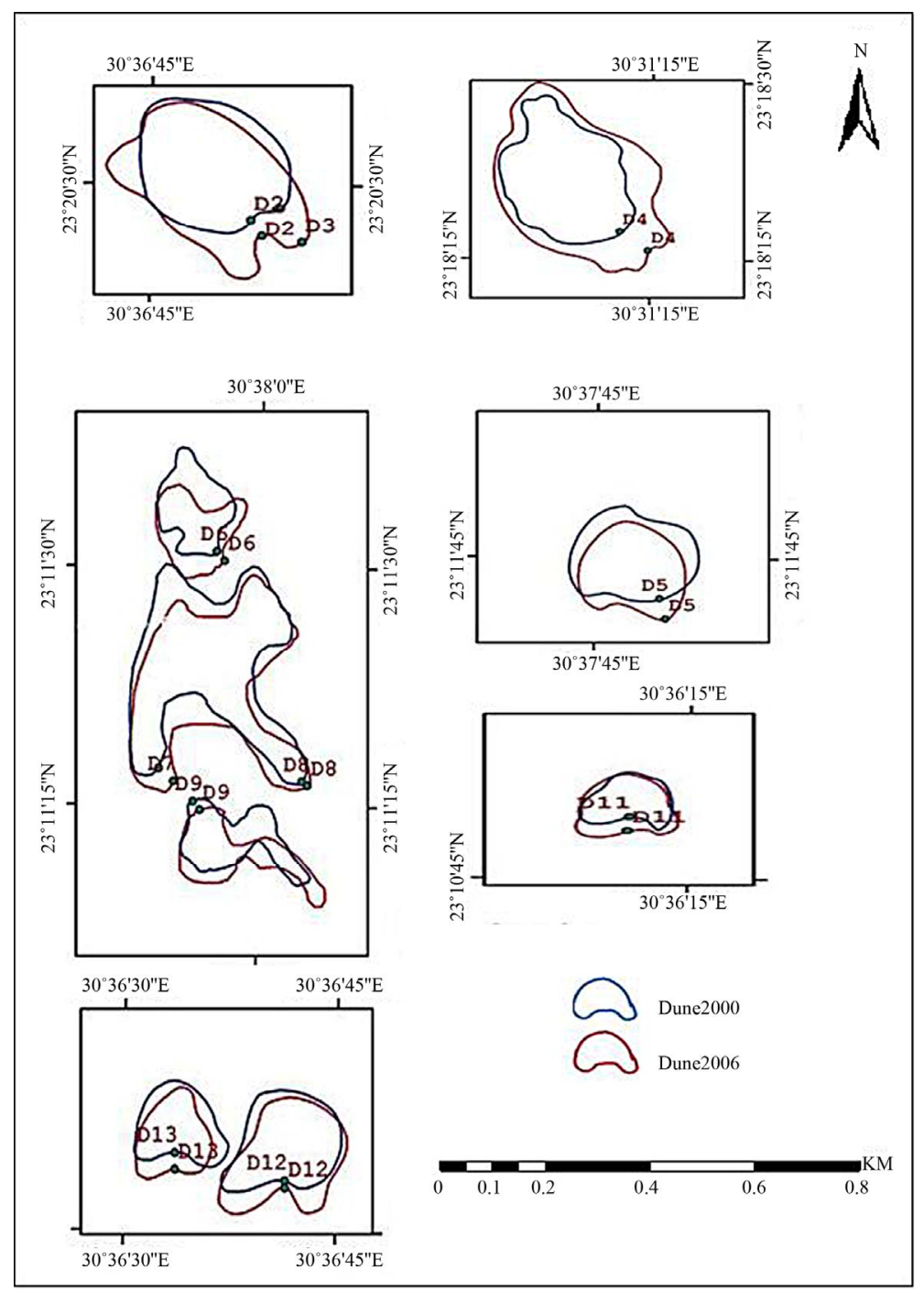

Figure 9. Dune movements at pilot area 5.
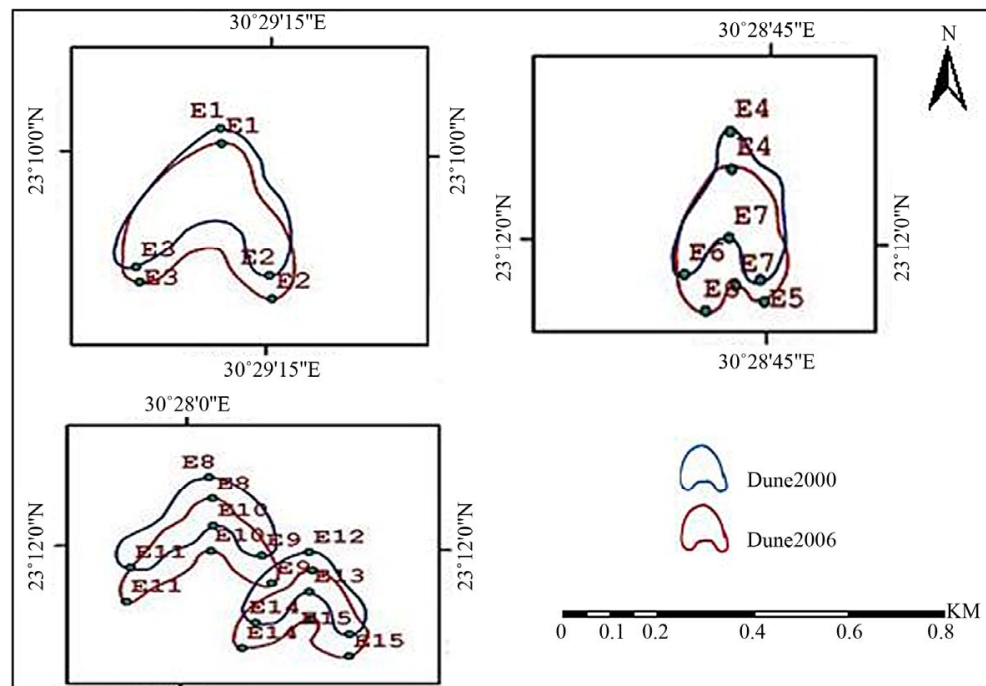

$30^{\circ} 28^{\prime} 0^{\prime \prime} \mathrm{E}$

Figure 10. Dune movements at pilot area 3. 


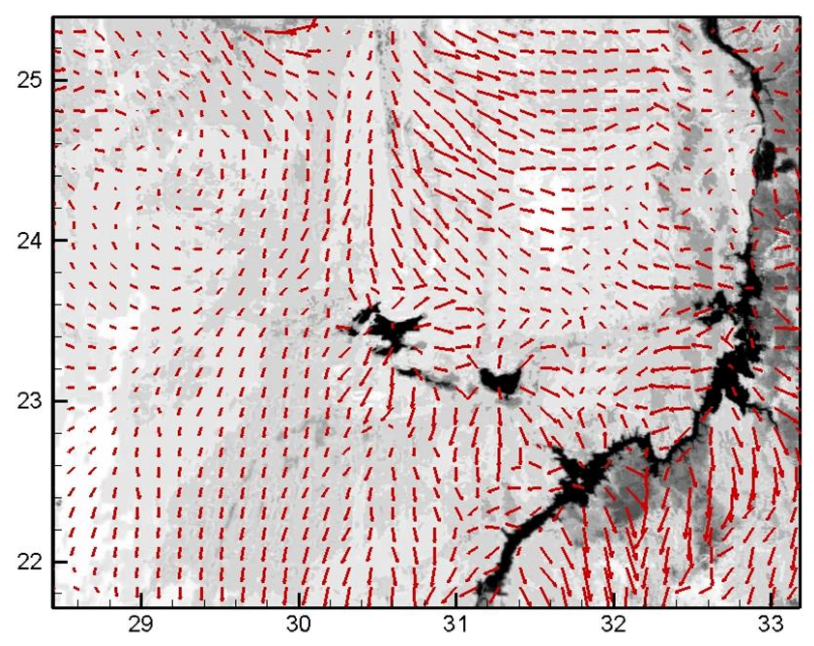

Figure 11. Simulation of the dominant wind direction in the area.

To help decision makers and planners for the newly development projects to reduce the natural hazards of sand dune movements, there is a need to study such threat using a tool to enable wide coverage. This is why remotely sensed data is an effective tool to achieve this objective. The use of satellite images enabled to understand on a wide coverage the sand dune system of Toshka Depression area and determine the rate of sand dune movements. In the 5 chosen pilot areas about 149 dunes (transverse dunes, barchans, and hybrid dune) were studied to estimate the actual rate of sand dune movements, which ranged from minimum of $1.3 \mathrm{my}^{-1}$ to a maximum of $19.3 \mathrm{my}^{-1}$. It is also well observed that some pilot areas such as pilot area 1 representing typical dune migrations with determined rate and direction; however other areas, such as pilot area 4, are reflecting dynamic changes in the morphology of the sand dunes. The estimated sand dune movements in this research were compared with some corresponding in-situ measurements by some previous researchers. Figure 12 shows the correlation between both results with $\mathrm{r}^{2} 0.86$, which means that $86 \%$ agreement of the estimated dune movements with the actual observed measurements. Such level of accuracy is acceptable to the level of mitigation minimizing the risk.

\section{Conclusion}

However, the dominant movement direction was estimated at almost South direction at angles from 270 to 290 degrees. Indeed, such high rate of movements has a direct impact on the spillway canal of Toshka lake, Sheikh Zayied Canal that feeds the agriculture planned areas, existing agriculture activities, infrastructures such as roads, and urbanized areas. Indeed, the outcomes of this research could help local authorities, decision makers and planners to mitigate or minimize the impact of sand dune movements on the newly planned project or the exiting

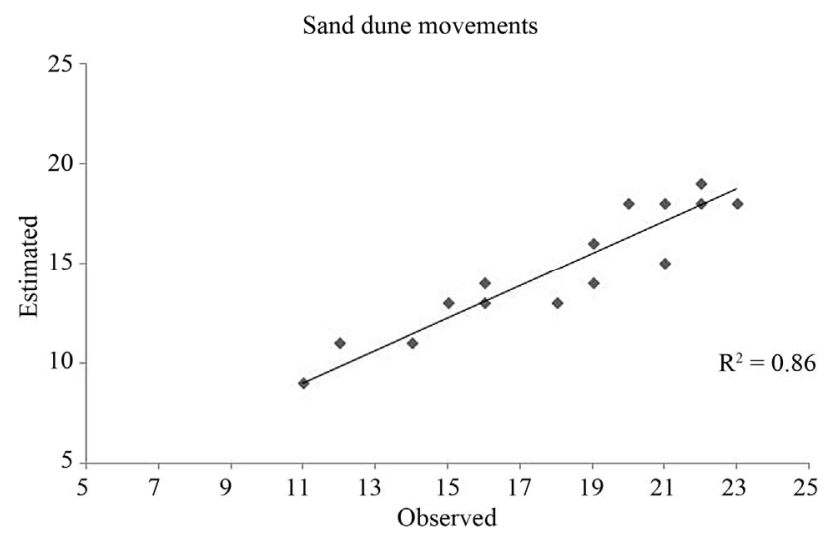

Figure 12. Observed versus estimated sand dune movements.

land use and land cover. The novelty of this study is the applicability to be robust for regular estimation of the sand dune movements and assessment of the hazards arisen from the sand dune movements on the developmental plans in the area.

\section{REFERENCES}

[1] Census Data of the Republic of Egypt (CAPMASS), "Egypt in Figures-Official Report," 2006.

[2] E. M. El Shazly and M. A. Abd El Hady, "Geology and Groundwater Conditions of Tushka Basin Area, Egypt," 11th International symposium on Remote sensing of Environment, Groundwater in Arid Areas in Egypt, 1977, pp. 25-29.

[3] N. S. Embabi, "The Geomorphology of Egypt. Land Forms and Evolution. Part 1. The Western Desert and the Nile Valley," Geographical Society of Egypt, 2004.

[4] I. Abou El-Magd and E. A. Hermas, "Human Impact on the Coastal Landforms in the Area between Gamasa and Kitchner Drains, Northern Nile Delta, Egypt," Journal of Coastal Research, Vol. 26, No. 3, 2010, pp. 541-548. http://dx.doi.org/10.2112/08-1172.1

[5] S. P. Gay Jr., "Observations Regarding the Movement of Barchan Sand Dunes in the Nazca to Tanaca Area of Southern Peru," Geomorphology, Vol. 27, No. 3-4, 1999, pp. 279-293.

http://dx.doi.org/10.1016/S0169-555X(98)00084-1

[6] A. W. Gifford, D. M. Warner and F. El-Baz, "Orbital Observations of Sand Distribution in the Western Desert of Egypt," In: F. El-Baz and D. M. Warner, Eds., Apollo-Soyuz Test Project, Summary Science Report, Vol. 2, Earth Observations and Photography, NASA Sp-412, Washington DC, 1979, pp. 219-236.

[7] E. A. Hermas, S. Leprince and I. Abou El-Magd, "Retrieving Sand Dune Movements Using Sub-Pixel Correlation of Multi-Temporal Optical Remote Sensing Imagery, Northwest Sinai Peninsula, Egypt," Remote Sensing of Environment, Vol. 121, 2012, pp. 51-60. http://dx.doi.org/10.1016/j.rse.2012.01.002

[8] N. S. Embabi, "Types and Patterns of Sand Dunes in Egypt," Bulletin de la Societe de. Géographie D'Egypte, 
Vol. 68, 1995, pp. 57-90.

[9] Environment and Climate Research Institute, "The Environmental Characteristics of Tushka Lakes," Final Report, National Water Research Center, Cairo, 2007.

[10] F. I. Khalaf and D. Al-Ajmi, "Aeolian Processes and Sand Encroachment Problems in Kuwait," Geomorphology, Vol. 6, No. 2, 1993, pp. 111-134. http://dx.doi.org/10.1016/0169-555X(93)90042-Z

[11] N. S. Embabi, "Sand Seas of the Western Desert of Egypt," In: A. S. Alsharhan, K. W. Glennie, G. L. Whittle and C. G. St. Kendall, Eds., Quaternary Deserts and Climatic Change, A. A. Balkema, Rottordam, 1998, pp. 495509.

[12] K. Pye and H. Tsoar, "Aeolian Sand and Sand Dunes," Unwin Hyman Lts., London, 1990. http://dx.doi.org/10.1007/978-94-011-5986-9

[13] H. Tsoar, "Dynamic Processes Acting on a Longitudinal Seif Sand Dunes," Sedimentology, Vol. 30, No. 4, 1983, pp. 567-578. http://dx.doi.org/10.1111/j.1365-3091.1983.tb00694.x

[14] M. M. Hosny and M. S. Abdelmoaty, "Assessment the Hazard of Sand Dune Movements on the Irrigation Canals, Toshka Project," 13th International Water Technology Conference, Hurghada, 2009, pp. 311-321.

[15] R. F. Misak and M. ElShazly, "Studies on Blown Sand at Some Localities in Sinai and Northern Desert, Egypt," Journal of Geology, Vol. 1, 1982, pp. 115-131.

[16] M. Khidr, "Aeolian Forms and Their Hazards in the West of Wadi El-Arish: A Geomorphological Study," PhD Dissertation, Geography Department, Ain Shams University, Egypt, 2006.

[17] H. Tsoar, D. G. Blumberg and Y. Stoler, "Elongation and Migration of Sand Dunes," Geomorphology, Vol. 57, No. 3-4, 2004, pp. 293-302. http://dx.doi.org/10.1016/S0169-555X(03)00161-2

[18] A. H. Ashri, "The Movement of Sand Dune at Kharga Oasis. Presented at the Eighth Annual Meeting," The Geological Society of Egypt, 1997, pp. 21-24.

[19] M. Hereher, "A Study on Sand Dunes Fields in North Sinai and the Environmental Risk Assessment of Aeolian Processes," MSc Thesis, Faulty of Science (Dumyat), Mansoura University, Egypt, 2000.

[20] M. S. ElBanna, "Geological Studies Emphasizing the Morphology and Dynamics of Sand Dunes and Their Environmental Impacts on the Reclamation and Developmental Areas in Northwest Sinai, Egypt," PhD Dissertation, Cairo University, Egypt, 2004.

[21] C. Y. Wang, J. J. Pu, T. J. Hua and Y. W. Liu, “Analysis and Usage of Space Remote Sensing Images," National Defence Industry Publishing House, Beijing, 1985, pp. 14-18.

[22] S. B. Yin and Y. H. Sarina, "Research on Sandy Desertification in Inner Mongolia by Remote Sensing and GIS," Journal of Arid Land Resources and Environment, Vol. 18, 2004, pp. 58-62.

[23] S. Leprince, S. Barbot, F. Ayoub and J. P. Avouac, "Automatic and Precise Ortho-Rectification, Coregistration, and Subpixel Correlation of Satellite Images, Application to Ground Deformation Measurements," IEEE Transactions on Geoscience and Remote Sensing, Vol. 45, No. 8, 2007, pp. $1529-1558$.

http://dx.doi.org/10.1109/TGRS.2006.888937

[24] S. Leprince, E. Berthier, F. Ayoub, C. Delacourt and J. P. Avouac, "Monitoring Earth Surface Dynamics with Optical Imagery," Eos, Transactions American Geophysical Union, Vol. 89, No. 1, 2008, p. 89. http://dx.doi.org/10.1029/2008EO010001

[25] J. G. Liu, R. Capes, M. Haynes and J. M. Moore, "ERS SAR Multi-Temporal Coherence Image as a Tool for Sand Desert Study (Sand Movement, Sand Encroachment and Erosion," The 12th International Conference and Workshop on Applied Geologic Remote Sensing, Denver, 1997, pp. 1-478

[26] J. G. Liu, P. G. Mason and J. Ma, "Measurement of the Left Lateral Displacement of Ms 8.1 Kunlun Earthquake on 14 November 2001 Using Landsat ETM+ Imagery," International Journal of Remote Sensing, Vol. 27, No. 10, 2006, pp.1875-1891.

[27] A. Warren and D. Allison, "The Palaeo Environmental Significance of Dune Size Hierarchies," Palaeogeography, Palaeoclimatology, Palaeoecology, Vol. 137, No. 3-4, 1998, pp. 289-303. http://dx.doi.org/10.1016/S0031-0182(97)00110-7

[28] C. S. Bristow and N. Lancaster "Movement of a Small Slipfaceless Dome Dune in the Namib Sand Sea, Namibia," Geomorphology, Vol. 59, No. 1-4, 2004, pp. 189196. http://dx.doi.org/10.1016/j.geomorph.2003.09.015

[29] Z. B. Dong, X. M. Wang and G. T. Chen, "Monitoring Sand Dune Advance in the Taklimakan Desert," Geomorphology, Vol. 35, No. 3-4, 2000, pp. 219-231.

[30] T. A. Maxwell and C. V. Haynes Jr., "Sand Sheet Dynamics and Quaternary Landscape Evolution of the Selima Sand sheet, South Egypt," Quaternary Science Review, Vol. 20, No. 15, 2001, pp. 1623-1647. http://dx.doi.org/10.1016/S0277-3791(01)00009-9

[31] Z. B. Dong, G. T. Chen, Z. W. Han, C. Z. Yan and Z. S. $\mathrm{Li}$, "The Blown Sand Disaster along Tarim Desert OilTransportation Highway," Chinese Journal of Environmental Science, Vol. 18, No. 1, 1997, pp. 4-9.

[32] Z. D. Zhu, S. Liu and X. M. Di, "Desertification and Rehabilitation in China," Science Press, Beijing, 1989.

[33] Z. D. Zhu, X. L. Zhao, Y. Q. Lin, Y. D. Hu and T. Wang, "Sandy Land Rehabilitation Engineering," China Environmental Science Publishing House, Beijing, 1998.

[34] O. A. Hassan and M. B. El-Leithy, "Monitoring of Sand Dunes Migration for Developing Mitigative Measures in El- Kharga Depression, Western Desert," The Egyptian Journal of Remote Sensing and Space Sciences, Vol. 7, 2004.

[35] J. Kim and M. Sultan, "Assessment of the Long-Term Hydrologic Impacts of Lake Nasser and Related Irrigation Projects in Southwestern Egypt," Journal of Hydrology, Vol. 262, No. 1-4, 2002, pp. 68-83. http://dx.doi.org/10.1016/S0022-1694(02)00013-6 